\title{
THE OPENING OF MALAYSIA CHINA KUANTAN INDUSTRIAL PARK ATTRACTS MAIN CHINA SHIPPING LINERS TO KUANTAN PORT
}

\author{
N.S.F. Abdul Rahman \& N.H. Zakaria \\ ${ }^{1}$ Department of Nautical Science and Maritime Transportation, School of \\ Ocean Engineering, Universiti Malaysia Terengganu \\ ${ }^{2}$ Department of Maritime Management, School of Maritime Business and \\ Management, Universiti Malaysia Terengganu \\ (nsfitri@umt.edu.my)
}

\begin{abstract}
The purpose of this paper is to determine the attractiveness of Kuantan Port as a hub port due to the opening of Malaysia-China Kuantan Industrial Park (MCKIP) using mathematical algorithms. The distance between both ports of origin and port of destination is one of the factors that will be evaluated in determining the relevance of selecting a hub port. The reason is that the shorter the route, the higher cost savings can be obtained. It is capable of helping China shipping liners in making decisions on which of Malaysia's ports can accommodate their vessels for cargoes loading and discharging processes. The result shows that Kuantan Port is the best port to be selected in terms of high-cost saving compared to other hub ports in Malaysia.
\end{abstract}

Keywords: MCKIP, Kuantan Port, China Shipping Liners, Maritime Business, SWOT and TOWS Matrix, Supply Chain.

\section{ACKNOWLEDGEMENT}

The authors would like to thanks, Universiti Malaysia Terengganu for giving the financial support and providing research facilities. 
The Opening of Malaysia-China Kuantan Industrial Park Attracts Main China Shipping Liners to Kuantan Ports

\section{Introduction}

Malaysia intends to expand the Malaysian economy in the bilateral relations with China through the establishment of the Malaysia-China Kuantan Industrial Park (MCKIP). China and Malaysia have jointly established the Malaysia-China Kuantan Industrial Park (MCKIP) and Qinzhou Industrial Park (QIP) to enhance the Malaysia-China foreign investments. The official launch of the Malaysia-China Kuantan Industrial Park moves a new chapter in the relationship between the two countries, a relationship that has matured beyond expectations (Lee and Sean, 2013). The establishment of MCKIP has been announced by the Malaysian Prime Minister, Datuk Seri Najib Tun Razak on February 5, 2013.

Kuantan Port is strategically situated at the eastern seaboard of Peninsular Malaysia, overlooking the major sea-lanes transiting the South China Sea linking Kuantan Port with the Pacific Rim. Kuantan Port Consortium (KPC) is a multi-purpose port operating in all weathers, 24-hours a day, 365 days a year and can handle a variety of products including dry bulk cargoes, containers, palm oil, chemicals, petroleum and steel pipes. Kuantan Port has upgraded and adapted the port to meet the ever-demanding requirements of the palm oil, chemical, container and mineral ore sectors.

Due to the location reason, Kuantan Port has a big potential for opportunities in handle cargoes from and to the Malaysia-China Kuantan Industrial Park (MCKIP) than the other competitor ports. The park boast highvalue industrial developments like steel mills, aluminium processing plant, edible oil processing plants and other high-value industrial developments.

The establishment of Malaysia-China Kuantan Industrial Park (MCIKP) located within ECER Malaysia is an effort to further strengthening the economic and trade relations between Malaysian Government and China. It is also the best way to develop Kuantan port to be a hub port in transaction transhipment of goods in trade between two countries. Kuantan Port offered the shortest, quickest and most direct route between Malaysia and the ports in the Far East. This study intends to analyse the possibility of Kuantan Port attracting main China Shipping Liners to dock at the port due to the opening of MCKIP at Kuantan, Pahang.

\section{Literature Review}

Ports play an important role in the country's international trade. To evaluate the competitiveness of Malaysian ports, a performance measurement of the 
ports can provide useful insights. Malaysia is strategically situated within the South East Asia region. The Straits of Malacca, one of the busiest shipping routes in the world, lies between the Peninsular Malaysia, and the island of Sumatra. Historically, Malaysia's main ports were built along the Straits of Malacca, taking advantage of its huge economic potential. This remains until today, with Port Klang, and the Port of Tanjung Pelepas being some of the more well-known Malaysian container ports. To evaluate the competitiveness of ports, performance measurement can be seen as an important tool in evaluating port productivity and efficiency (Tongzon, 1995; 2001).

China and Malaysia have jointly established the Malaysia-China Kuantan Industrial Park (MCKIP) and Qinzhou Industrial Park (QIP) to further boost bilateral trade and investment between them (Leng, 2013). MCKIP, which is situated in Pahang, plays as the gateway for bringing investment and jobs into the Malaysia Eastern Corridor, which covers an economically lagging area on the peninsula. To achieve the expected China FDI target, Malaysia will quickly need to draw in China FDI equivalent.

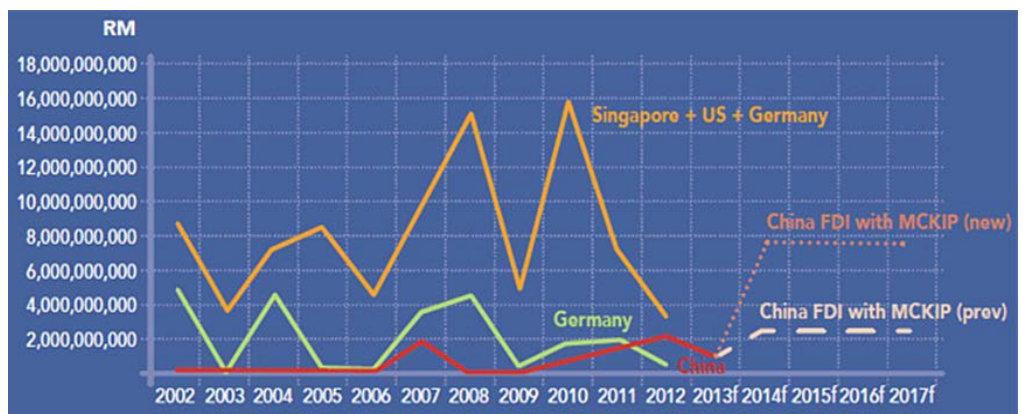

Figure 1. Malaysia's key FDI sources and forecasts, China FDI with MCKIP Source: Leng (2013)

Figure 1 shows the forecast of the economic growth in foreign direct investment from China. From the graph above, Malaysia was receiving the highest foreign direct investment from Singapore. It's recorded the highest foreign investment occured in 2010 which recorded RM 16 billion. This graph illustrates the growth of FDI rate by the establishment of the Malaysia-China Kuantan Industrial Park in 2013. With the establishment of MCKIP, the China FDI probably increased above RM 2.0 billion. Malaysia's key imports from China are electronics, integrated circuits and micro assemblies, automatic data processing machines, ICT equipment, office equipment, printed circuits, electrical transformers and transport equipment. The opening of the MCKIP whose proximity to Kuantan Port will be able to attract the main China 
shipping liners to Kuantan Port in transitioning loading and discharging cargoes. Kuantan Port has its attractiveness to invite the China shipping liners to use their service.

However, the efficiency of the port not only for port productivity and performance but also in journey time and transportation costs. Currently, the same measures for travel time and other benefits are used regardless of income levels and regions. According to Fink et al., (2000), analysing the determinants of maritime transport costs in 1998, focusing on the effect of non-competitive public and private policies, they found that the latter have a significant effect on transport costs. But, what about other factors influencing transport costs. There are wide consensuses on the crucial importance of port activities for the transport services.

Conventional notions of port choice have focused on geographical location as one of the main determinants of a port's attractiveness (Hiling and Hoyle, 1984). The choice of a port is not merely a function of proximate convenience but derives considerable implications as well from the overall transit costs of cargo trafficking. The geographical locations of two ports are very influential in the cost of transport. According to Baier and Bergstrand (2001), the obvious and most studied determinant of transport cost is geography, particularly distance. The greater the distance between two markets, the higher the expected transport cost for their trade. In another study, Wang et al., (2013) measure the bunker consumption of a ship, on the one hand, depends on the design and structure of the ship, and it is, on the other hand, very sensitive to the sailing speed. This study focuses on the impact analysis of sailing speed on bunker consumption. When the speed increases, the bunker consumption increases more than normal.

This study uses the SWOT Analysis to analyse the strength, weakness, threat and opportunities of the project. SWOT Analysis is to analyse the environments both internally and externally to identify the strength and weakness as well as to optimise their opportunities and reduce the threats to the company. The SWOT analysis, like strategic planning, has received much attention since the early 1960s (Delahaye, 2000). In a business environment, it is the key to strategic planning to enhance organisational performance and match the activities of an organisation to its environment and its resource capabilities (Johnson and Scholes, 1989). 


\section{Background of Method}

A mixed mode of data collection process containing of qualitative and quantitative research method is used in this study. For the qualitative data set, some interview sessions and sets of questionnaires consist of the efficiency of handling facilities, technology, equipment, workforce, total number of birth, draft and harbour, are used for obtaining feedbacks from technical experts who are the top management of Kuantan Port Consortium (KPC). While, the quantitative dataset is obtained from Kuantan Port annual report and Marine Department, Malaysia.

Three mathematical algorithms are used for analysing the journey time calculation (Notteboom and Vernimment, 2009), bunker fuel consumption (Stopford, 1997), and the bunker fuel equation (Magelssen, 2010). The mathematical calculations aim to calculate the journey time of ship and the cost required for a journey. Finally, a SWOT analysis is a structured planning method that will be used to evaluate the strengths, weaknesses, opportunities, and threats involved in this study.

Step 1.The journey time calculation, (Notteboom and Vernimment, 2009).

$$
\text { Journey time }=\frac{D}{V \times 24}
$$

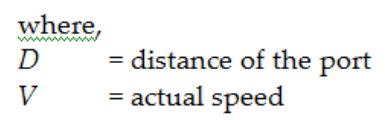

Equation 1 needs the important element, which ' $\mathrm{D}$ ' is the distance of the port to the port destination. ' $\mathrm{V}$ ' is the design speed during the navigation. This equation calculates in different service speed of the vessel to get the total day at sea with the different distance port destination.

Step 2 .The fuel consumption calculations (Stopford, 1997)

$$
\begin{aligned}
& \text { msME }=F^{*}\left(\frac{S}{S^{*}}\right)^{\alpha} \\
& \text { where, } \\
& m s M E=\text { actual fuel consumption (tonnes/day) } \\
& F^{*} \quad=\text { design fuel consumption } \\
& S \quad=\text { actual speed } \\
& S^{*} \quad=\text { design speed }
\end{aligned}
$$


The exponent $\alpha$ has a value of about three for diesel engines and two for steam turbines. It follows the cube rule where the fuel level is very sensitive to speed, and As for any speed or fuel consumption, everything depends on hull design and smoothness of the hull. These variables mean that there can be a very wide disparity between the fuel consumption of vessels of a similar size and speed. Obviously, the importance of cost and its difference in efficiency depends on the price of fuel.

Step 3. The bunker fuel cost calculation, (Magelssen, 2010).

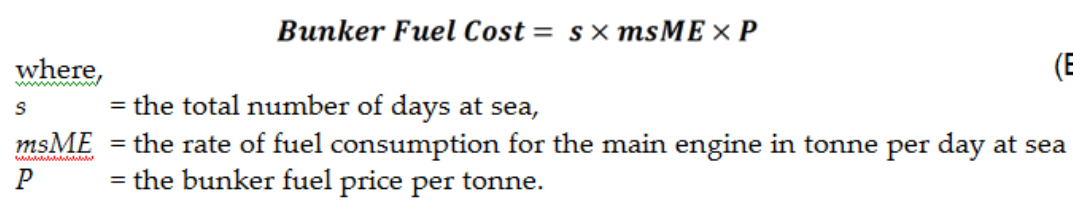

To gets the true assumption of bunker fuel costs, the several elements should be identified in the difference of service speed. The rate of service speed will influence the requirements of bunker fuel costs, and followed by the day at sea, fuel consumption and bunker fuel price.

\section{Journey Time and Costs Calculations}

The objective of this study is to analyse the attractiveness of Kuantan Port which is facing the South China Sea that has the big potential to be a hub port. This research intends to analyse the attractiveness of Kuantan Port Consortium in terms of location and distance from one point to the point of destination. Three mathematical calculations can achieve this objective are used to analyse the aspects of time journey and cost saving of Kuantan Port compared to the others hub ports in Malaysia such as Port Klang, Port Tanjung Pelepas and Johor Port. In general, the distance between Shanghai Port and Kuantan Port is about 2025 nautical miles (nm). This distance is shorter compared to the other three main ports in Malaysia, which are Johor Port (2142nm), Port of Tanjung Pelepas (2172nm) and Port Klang (2431nm) (Figure 2). Figure 2 shows the distance of four selected main ports in Malaysia from Shanghai Port. It can be summarised that Kuantan Port is the shortest distance port compared to other ports, which can help China Shipping Liners save the journey time and vessel operational cost. 
Shanghai Port

Shanghai Port

Shanghai Port

Shanghai Port
2025 nautical miles

2142 nautical miles

2172 nautical miles

2431 nautical miles
Kuantan Port

Johor Port

Port Tanjung Pelepas

Port Klang

Figure 2. The different port distance of four ports in Malaysia from Shanghai Port.

Step 1 . The journey time calculation

After obtaining the distance information of those ports, the journey time calculation can be computed using Equation 1 as described in Section 3. Given Kuantan Port as an example, the journey time is as follows:

\section{Kuantan Port}

When service speed is 25 knots, time at sea $\quad=2025 \div(25)(24)=3.38$ days

When service speed is $22 \mathrm{knots}$, time at sea $\quad=2025 \div(22)(24)=3.84$ days

When service speed is $18 \mathrm{knots}$, time at sea $\quad=2025 \div(18)(24)=4.69$ days

Table 1 The journey of time data associated with the vessel speed from

Shanghai Port

\begin{tabular}{|l|l|l|l|l|}
\hline \multirow{2}{*}{ Port } & \multirow{2}{*}{$\begin{array}{l}\text { Distance } \\
\text { (Nautical Miles) }\end{array}$} & \multicolumn{3}{|l|}{ Day at sea/speed (knots) $\mathbf{f}^{\mathbf{*}}$} \\
\cline { 3 - 5 } & $\mathbf{2 5}$ (knots) & $\mathbf{2 2}$ (knots) & $\mathbf{1 8}$ (knots) \\
\hline Kuantan Port & $2025 \mathrm{~nm}$ & 3.38 days & 3.84 days & 4.69 days \\
\hline Johor Port & $2152 \mathrm{~nm}$ & 3.59 days & 4.08 days & 4.98 days \\
\hline $\begin{array}{l}\text { Port Tanjung } \\
\text { Pelepas }\end{array}$ & $2172 \mathrm{~nm}$ & 3.62 days & 4.11 days & 5.03 days \\
\hline Port Klang & $2431 \mathrm{~nm}$ & 4.05 days & 4.60 days & 5.60 days \\
\hline
\end{tabular}

By using the similar calculation process, the journey time to other ports is shown in Table 1 . The calculation clearly described that the time saving through the different distance of Kuantan Port 2025 nautical miles from Shanghai Port is more compared to other main ports in Malaysia. By using the service speed of 25 knots, 22 knots and 18 knots, the comparison on saving time between Kuantan Port and Port Klang are 0.67 days (3.38 days -4.05 days $=-0.67$ days) when using 25 knots, 0.76 days when using 22 knots and 0.91 days when using 18 knots. 
The Opening of Malaysia-China Kuantan Industrial Park Attracts Main China Shipping Liners to Kuantan Ports

Step 2. The fuel consumption calculations

Next, the fuel consumption calculation will be computing using Equation 2 as described in Section 3.

When service speed is 18 knots, $\mathrm{FC}=266.69(18 \div 25) 3=99.40$ tonnes/day When service speed is 22 knots, $\mathrm{FC}=266.69(22 \div 25) 3=181.74$ tonnes/day When service speed is 25 knots, FC $=266.69(25 \div 25) 3=266.69$ tonnes/day

From the calculation above, these are calculated with the different service speed of vessel 18 knots, 22 knots, and 25 knots. The difference in service speed of vessel will influence the consumption of bunker fuel. The container ship was selected in 6,600 TEU with the assumption of bunker consumption of 266.69 tonne as in the paper of Abdul Rahman (2012).

Table 2 The bunker fuel cost data

\begin{tabular}{|c|c|c|c|c|c|}
\hline Port & $\begin{array}{l}\text { Speed } \\
\text { (knots) }\end{array}$ & $\begin{array}{l}\text { Day at } \\
\text { sea }(s)\end{array}$ & $\begin{array}{l}\text { Fuel } \\
\text { consumption } \\
\text { per day } \\
(M S M E)\end{array}$ & $\begin{array}{l}\text { Bunker fuel } \\
\text { price per } \\
\text { metric } \\
\text { tonne }(P)\end{array}$ & $\begin{array}{l}\text { Bunker Fuel } \\
\text { Cost } \\
s \times m s M E \times P\end{array}$ \\
\hline $\begin{array}{l}\text { Kuantan } \\
\text { Port }\end{array}$ & $\begin{array}{l}18 \\
22 \\
25\end{array}$ & $\begin{array}{l}4.69 \\
3.84 \\
3.38\end{array}$ & $\begin{array}{l}99.40 \\
181.74 \\
266.69\end{array}$ & $\begin{array}{l}\$ 644.00 \\
\$ 644.00 \\
\$ 644.00\end{array}$ & $\begin{array}{l}\$ 300,223.78 \\
\$ 449,435.75 \\
\$ 580,509.46\end{array}$ \\
\hline Johor Port & $\begin{array}{l}18 \\
22 \\
25\end{array}$ & $\begin{array}{l}4.98 \\
4.08 \\
3.59\end{array}$ & $\begin{array}{l}99.40 \\
181.74 \\
266.69\end{array}$ & $\begin{array}{l}\$ 644.00 \\
\$ 644.00 \\
\$ 644.00\end{array}$ & $\begin{array}{l}\$ 318,787.28 \\
\$ 477,525.48 \\
\$ 616,576.61\end{array}$ \\
\hline $\begin{array}{l}\text { Port Tanjung } \\
\text { Pelepas }\end{array}$ & $\begin{array}{l}18 \\
22 \\
25\end{array}$ & $\begin{array}{l}5.03 \\
4.11 \\
3.62\end{array}$ & $\begin{array}{l}99.40 \\
181.74 \\
266.69\end{array}$ & $\begin{array}{l}\$ 644.00 \\
\$ 644.00 \\
\$ 644.00\end{array}$ & $\begin{array}{l}\$ 321,988.40 \\
\$ 481,036.70 \\
\$ 621,729.06\end{array}$ \\
\hline $\begin{array}{l}\text { Port } \\
\text { Klang }\end{array}$ & $\begin{array}{l}18 \\
22 \\
25\end{array}$ & $\begin{array}{l}5.60 \\
4.60 \\
4.05\end{array}$ & $\begin{array}{l}99.40 \\
181.74 \\
266.69\end{array}$ & $\begin{array}{l}\$ 644.00 \\
\$ 644.00 \\
\$ 644.00\end{array}$ & $\begin{array}{l}\$ 358,476.16 \\
\$ 538,386.57 \\
\$ 695,580.85\end{array}$ \\
\hline
\end{tabular}

Note: The price of 380cst was\$644.00in October 2013 per tonne (Shanghai Port)

Step 3. The bunker fuel cost calculation

After obtaining the information in Steps 1 and 2, the bunker fuel cost can be calculated using Equation 3 as described in Section III. To get the actual amount of bunker fuel costs, several elements should be identified in the different service speeds. A service speed will influence the requirements of 
bunker fuel costs, and followed by the day at sea, fuel consumption and bunker fuel price.

Table 2 shows the bunker fuel cost of the selected ports in different distances from Shanghai Port. The cost of bunker fuel is calculated in the different speed services which are in 18 knots, 22 knots and 25 knots. The oil price is $\$ 644.00$ in October 2013 per tonne based on Shanghai Port market. It can be analysed that the distance of Shanghai Port to the Kuantan Port is only 4.69 days compared to Port Klang which is at 5.60 days both using the service speed of 18 knots. It may save 0.91 days per day. From the bunker fuel cost comparison of four ports, it shows that the bunker fuel cost of China Shipping Liners will be most cost efficient when they choose Kuantan Port as the selected port for handling cargoes due to the distance compared to others. The bunker fuel cost saving is between $6 \%$ and $19 \%$ in comparison (Figure 3).

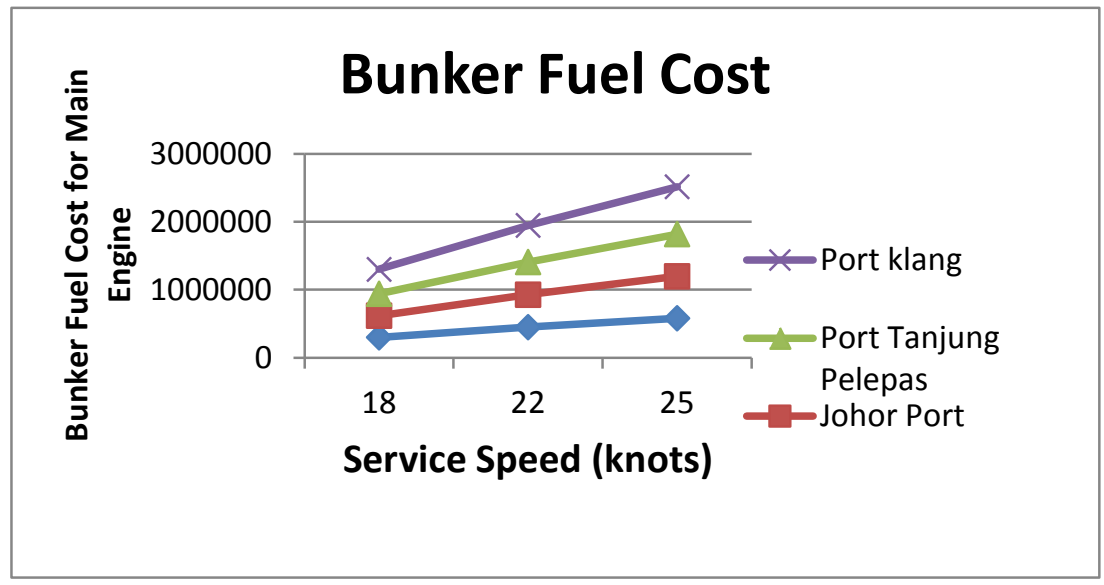

Figure 3. The comparison between bunker fuel cost and service speed between four major port in Malaysia from Shanghai Port.

The graph above shows the different levels of fuel consumption. To make the assumption of the consumption of fuel cost, the service speed has been identified with the different speed, which 18 knots, 22 knots, and 25 knots. The design service speed was chosen in extra slow steaming, slow steaming, and normal speed. The design speed of 18 knots was considered in extra slow steaming. It is a substantial decline in speed for the purpose of achieving a minimal level of fuel consumption while still maintaining a commercial service. It can be typically applied to specific short distance routes. The service speed of 22 knots and 25 knots was considered as normal speed, which 
represents the optimal cruising speed of container ship and its engine has been designed to travel.

By using the different design speed of the vessel, we can analyse the difference of the bunker fuel cost consumption in the container ship 6600 TEU. We can see that the Port Klang is the most distant from the Shanghai Port with 2431 nautical miles compared to Kuantan Port 2025 nautical miles. In general, the distance of port to another port will be influencing the bunker fuel cost.

From analysing the bunker fuel cost in the data, the assumption of bunker fuel cost consumption per day in Kuantan Port by using slow steaming of 18 knots speed service are $\$ 300,223.78,449,435.75$ at a service speed of 22 knots and $\$ 580,509.46$ at the high service speed of 25 knots. It is most saving cost compared to the others port. It can be seen in a comparison of Port Klang, which by using the service speed at 18 knots, the bunker fuel consumption costs are $\$ 358476.16$. It means that the ownership of shipping liners will be saving about $\$ 58,252.38$. With the assumption, if the ship frequency is eight times for a year, they will be saving the cost of about $\$ 466,019.04$ for a year. Same goes to the another design speeds, which it may have a saving cost of about $\$ 711,606.56$ at a service speed of 22 knots years, Whereas if the assumption at the high-speed service of 25 knots, it may have a saving cost of about $\$ 920,571.12$ for a year. It is the big amount for shipping industry cost and may get the much revenue by saving of bunker fuel cost.

Also, we can analyse the different bunker fuel cost of the others ports in Port Tanjung Pelepas and Johor Port. Port Tanjung Pelepas is the second last destination before the Port Klang with the distance of 2172 nautical miles from the Shanghai Port. By using the different service speed of container vessel of 6600 TEU in 18 knots, 22 knots, and 25 knots, these are the different assumptions of fuel consumption cost $\$ 174,116.96, \$ 252,807.6, \$ 329,756.8$ for a year.

Lastly, the Johor Port situated 2142 nautical miles from Shanghai Port. The same goes for the different service speed such another port slow steaming speed of 18 knots as well as normal steaming speed of 22 knots and 25 knots. In this assumption the ship frequency is set 8 times, it may save cost about $\$ 148,508$ at 18 knots. When the service speed at 22 knots, it may have a savings cost of about $\$ 224,717.84$. Also, when the service speed was set at 25 knots, it may save cost about $\$ 148,508$ for a year. From the assumption of the four selected port, the Kuantan Port is the best way to reduce the cost and time during the navigation. 


\section{Swot/Tows Analysis of Kuantan Port}

\section{SWOT Matrix}

A SWOT analysis (alternatively SWOT Matrix) is a structured planning method used to evaluate the strengths, weaknesses, opportunities, and threats involved in a project. SWOT analysis is a framework for identifying and analysing the internal and external factors that can have an impact on the viability of a project. This research is using the SWOT Analysis to analyse the readiness and capability of Kuantan Port to receive the main China shipping liner due to the opening of MCKIP at Gebeng. The SWOT analysis provides information that is helpful in matching the firm's resources and capabilities to the competitive environment in which it operates. Kuantan port has a big strength in its strategic location facing the South China Sea and in the middle of the busiest shipping lanes in the world. Kuantan Port is the shortest, quickest and most direct route between Malaysia and the ports in the Far East. The shipping community stood to benefit in terms of cost savings and reduction in shipping time. Kuantan Port also facilitates with multipurpose berths such as palm oil berth, mineral oil berth, liquid chemical berth, container berth, dry bulk berth, and others. It is also able to provide a host of ancillary services including on-dock depot services, fumigation, water supply, bunkering, slop reception and warehousing. Besides, Kuantan Port provides the variety of storage such as container storage, general storage, dangerous goods storage, tank farm and pipe rack system.

However, the small berth area $3.4 \mathrm{~km}$ is the weakness of Kuantan Port to receive more of the China shipping liners due to the opening of MCKIP. Also, cargo handled of dry bulk take long handling time compared to containers which are cargo-dependent. By the establishment of MalaysiaChina Kuantan Industrial Park (MCKIP), it is indirectly stressing on the Kuantan Port itself in the aspect of technology and facilities of Kuantan Port. The commodities of goods will flows in and out for everyday in transaction loading and unloading of goods. The Kuantan port should be ready to provide enough equipment in the operation activities such as Quay crane, Prime Movers, Forklift Trucks, Mobile Cranes and other mechanical equipment to facilitate the handling operation to avoid delays. It also includes the providing of the capability of the storage area to store the goods properly and reduce the turnaround time of ships at port. Kuantan's location in the South China Sea offers the quickest and most direct route to major ports and has the biggest opportunity to attract foreign investors from the Far East country to invest in Malaysia. Malaysia has become the first Southeast Asian nation to establish 
The Opening of Malaysia-China Kuantan Industrial Park Attracts Main China Shipping Liners to Kuantan Port

diplomatic relations with China. It was the beginning of a partnership of great promise.

Table 3 The table shows the Swot analysis of Kuantan Port

\begin{tabular}{|c|c|}
\hline Strength & Weakness \\
\hline $\begin{array}{l}\text { 1.Strategic location facing South China Sea® } \\
\text { 2.Deepwater Port } \\
\text { 3.Advantages port handling facilities } \\
\text { 4. Excellent Connectivity to Hinterland } \\
\text { - rail and road transportation network will } \\
\text { provide seamless connectivity to the } \\
\text { hinterland. } \\
\text { 5. Short Sea Transport Capabilities. } \\
\text { 7. Well-trained workforce. } \\
\text { 8. Pipe rack system }\end{array}$ & $\begin{array}{l}\text { 1. Small berth area } 3.4 \mathrm{~km} \text {. } \\
\text { 2. Cargo handled of dry bulk take long } \\
\text { handling time compared to containers } \\
\text { which are cargo-dependent.๑) }\end{array}$ \\
\hline Opportunities & Threats \\
\hline $\begin{array}{l}\text { 1. Kuantan Port can attract the local and } \\
\text { foreign investor in Far East country. } \\
\text { 2. Boost the trade between Malaysia and } \\
\text { China. } \\
\text { 3.technology changes } \\
\text { 4. Opportunities to be a hub port. } \\
\text { 5. Petrochemical Hub Of The Region and } \\
\text { Palm Oil Industrial Cluster (POIC) }\end{array}$ & $\begin{array}{l}\text { 1. Improve the use of technology and good } \\
\text { handling practices. } \\
\text { 2. Cost expansion of Kuantan Port. } \\
\text { 3. Competition with the others hub port. }\end{array}$ \\
\hline
\end{tabular}

\section{TOWS Matrix}

After analysing in the SWOT analysis, the TOWS Matrix is the effective way to analyse the strategies and new tactics of the company. General assumption of Tows analyses is that a good strategy maximises strengths and opportunities and minimises threats and weaknesses. Four different strategy types can be considered. First, SO-Strategies: internal strength(s) can be used to realise external opportunity(ies) (ideal case), second, WO-Strategies: reduce internal weakness(es) or develop missing strength (s) to realise external opportunities, third, ST-Strategies: internal strength(s) are used to minimise external threats and fourth, WT-Strategies: reduce the internal weakness(es) to avoid external threats (only defensive strategy, worst case scenario). The aim of the strategy formulation is to produce possible and attractive strategies.

Table 4 TOWS Analysis of Kuantan Port Consortium (KPC) 


\begin{tabular}{|c|c|c|}
\hline & $\begin{array}{l}\text { Strength (S) } \\
\text { 1.Strategic location-facing the } \\
\text { South China Sea } \\
\text { 2.Deepwater Port } \\
\text { 3.Advantages port handling } \\
\text { facilities } \\
\text { 4. Excellent Connectivity to } \\
\text { Hinterland } \\
\text { - rail and road transportation } \\
\text { network will provide seamless } \\
\text { connectivity to the hinterland. } \\
\text { 5. Short Sea Transport } \\
\text { Capabilities. } \\
\text { 7. Well-trained of workforce. } \\
\text { 8. Pipe rack system }\end{array}$ & $\begin{array}{l}\text { Weakness }(\mathbf{W}) \\
\text { 1. Small berth area } 3.4 \mathrm{~km} \text {. } \\
\text { 2. Cargo handled of dry } \\
\text { bulk take long handling } \\
\text { time compared to } \\
\text { containers which are } \\
\text { cargo-dependent. }\end{array}$ \\
\hline $\begin{array}{l}\text { Opportunities (O) } \\
\text { O1. Kuantan Port can attract } \\
\text { the local and foreign investor } \\
\text { in Far East country. } \\
\text { O2.Boost the trade between } \\
\text { Malaysia and China. } \\
\text { O3.technology changes } \\
\text { O4.Opportunities to be a hub } \\
\text { port. } \\
\text { O5.Petrochemical Hub Of } \\
\text { The Region and Palm Oil } \\
\text { Industrial Cluster (POIC) }\end{array}$ & $\begin{array}{l}\text { Strategy (SO) } \\
\text { S1,S6,O1,O4,O6 } \\
\text {-Promotion incentives by Kuantan } \\
\text { Port and government. } \\
\text { S3, O3, O4 } \\
\text {-enhance the technology system, } \\
\text { Communications and Information } \\
\text { Comprehensive. } \\
\text { S7, O3 } \\
\text {-enhance Ideal Human Capital }\end{array}$ & $\begin{array}{l}\text { Strategy (WO) } \\
\text { W1,O1,04 } \\
\text {-expand the berth area off } \\
\text { to receive more ship berth. } \\
\text { W3, O5 } \\
\text {-Improve holistic transport } \\
\text { network }\end{array}$ \\
\hline $\begin{array}{l}\text { Threats (T) } \\
\text { T1. Improve the use of } \\
\text { technology and good } \\
\text { handling practices. } \\
\text { T2. Cost expansion of } \\
\text { Kuantan Port. } \\
\text { T3. Competition with the } \\
\text { others hub port. }\end{array}$ & $\begin{array}{l}\text { Strategy (ST) } \\
\text { S2,S3, T1,T2 } \\
\text {-research and development } \\
\text { S3, T1 } \\
\text {-improve the quality ICT services }\end{array}$ & $\begin{array}{l}\text { Strategy (WT) } \\
\text { W1,T1,T2 } \\
\text {-build strong cooperation } \\
\text { with the China company } \\
\text { and government. } \\
\text { W3, T3 } \\
\text {-improve the excellent } \\
\text { Connectivity to Hinterland }\end{array}$ \\
\hline
\end{tabular}

As described in Table 4, it has been common in the past to suggest that companies identify their strengths, weaknesses, opportunities and threats in the internal and external environment (Heinz, 1977). The process of strategy formulation in the table above analyse the internal and external of Kuantan Port and come out with the strategy and tactic which refers to action plans by which strategies are executed. 
The Opening of Malaysia-China Kuantan Industrial Park Attracts Main China Shipping Liners to Kuantan Port

\section{Strategies and Opportunities (SO) 1}

Kuantan Port is located at the strategic location facing the South China Sea that has a great potential to attract the foreign investor in Far East country. Furthermore, Kuantan Port provides the pipe rack system that opens the opportunities to the Kuantan Port to be a Petrochemical Hub of the Region and Palm Oil Industrial Cluster (POIC). Also, the MCKIP will invest in the refinery palm oil plant in the Gebeng Industrial area. The role of government and Kuantan Port are crucial to making the promotion incentives to the others countries to attract the investor. Besides, enhancing the technology system, for communications and Information Comprehensive to enable to meet effectively the management and operation as well as in increasing the ideal human capital which has mastery in communication skills, management skills and operation skills.

\section{Weakness and Opportunities (WO)}

Kuantan Port is a small berth area about the $3.4 \mathrm{~km}$ and poor road linkage. But, Kuantan Port has a deep water port which includes a harbour channel deepened to a depth of $16.5 \mathrm{~m}$ with possible deepening to $18 \mathrm{~m}$. This will allow larger and more modern ships to call with the advantage of reducing transportation costs due to increased frequency and economics of scale. In order to achieve the opportunities to be a hub port, there should be an improvement in the holistic transport network including the road, rail, air and sea transport to meet the efficiency of Integrated Logistic.

\section{Strengths and Threats (ST)}

The Kuantan Port has a deep-water port. It can benefit and attract the local and foreign investors. The Kuantan Port is equipped with ample Port Handling Facilities. But for the future, Kuantan Port should be provided with the latest technologically advanced equipment and cargo handling facilities to significantly improve efficiency and turnaround time as well as to improve the quality of ICT services in management and operation at the port such as cargo tracking and EDI systems. The research and development are required to maintain the sustainability and efficiency of the port.

\section{Weakness and Threats (WT)}

The weakness of the port is that it has a small berth area and poor road linkage that is a threat to improving the use of technology and good handling practices, cost expansion of Kuantan Port, and competition with the others hub port can be solved by the relevance strategy to overcome the problems. 
Kuantan Port could build strong cooperation with China and the Malaysian government. According to the News Straits Times 2013, KPC can expect to see significant investments from Guangxi, with the company set to pour RM7 billion into the MCKIP and surrounding infrastructure, either directly or via joint ventures with Malaysian companies. This opportunity can be seen as too open the big potential to attract the Far East country investors to invest in Malaysia. On the other hand, improving the excellent connectivity to hinterland is one strategy that should be considered to fulfill the vision of being a hub port. A study is currently underway for a rail system to connect the East Coast to the Klang Valley via Kuantan, while the new KPC Port Link Road will connect the Port directly to the East Coast Expressway.

\section{Discussion and Conclusion}

Due to the opening of Malaysia-China Kuantan Industrial Park (MCKIP) at Gebeng, the big opportunities of the KPC to become a mega port in Peninsular Malaysia is of great possibility. It is not just attract the China's investor, but it also has the big potential to attract foreign direct investments from the Far Eastern Countries. The government plays the main player of this venture to attract the foreign investors to invest in the ECER, especially in Gebeng Industrial Area. The KPC development will see the Gebeng area developed into an ultra-modern industrial region servicing the petrochemical and manufacturing industries primarily.

The hinterland access is the important factor for the development of the port. Various scholars have argued that hinterland access is important for the competitiveness of seaports (Notteboom, 1997). In order to implement this strategy, changes in the administrative structure of port authorities are necessary (Van Klink, 1995). The development of the multimodal transport network is an important way to enhance the continuous sustainability in integrated logistics management, including the rail, road transport, air and sea way. Besides, there is a need to improve the infrastructure road network to meet the hinterland access. Currently underway is a rail system to connect the East Coast to the Klang Valley via Kuantan, while the new KPC Port Link Road will connect the Port directly to the East Coast Expressway (LPT 2), which is the effective way in the road transport network.

For recommendation, Kuantan Port should be ready to receive more coming of China Shipping liners regarding strategy to expand its services. Kuantan Port has the advantage that is very useful for it to become the gateway to the development of the Malaysian economy. The strategic location 
which is located facing the South China Sea is a benefit to ECER in attracting more shipping berth at Kuantan Port. This strategic location offers the quickest and fast route from the Far East Country. The Kuantan Port management should be taking the effective alternatives to prepare for cargo operations and management of the port. Other than fulfilling customer demand for the delivery of high-quality services at competitive prices, there is also the need to strengthen feeder connections within the region and generate greater intraregional and external trade.

In order to achieve the successful port management, the employee skill is another important aspect that needs to be taken into account in company growth. The Human Resource Division must be dedicated to recruiting and retaining good staff and enabling their engagement and growth with the company. The port performance should be driven by the human skills which are 'getting the right people' and 'getting the people right'. At the organizational level, Port Performance comprises the three basic outputs which are effectiveness, efficiency, and port personnel satisfaction (Marios, 2006). It is important to point out that the provision of opportunities for appropriate training, education and development is one of the proven strategies for port workforce motivation which have been taken into account by the ILO when developing its port-related training programmes. Many people throughout the world, particularly in the developing countries, work extremely hard but have little output. The key is not working harder but working smarter. 'Working Smarter' in a port terminal would mean such as eliminating unnecessary tasks, developing a strong sense of teamwork, providing continuous training of workers about how to do their jobs and in problem-solving.

The best way to cope with the many handling activities is to provide adequate handling equipment to facilitate the cargo handling, dredging deep water, and expanding the storage area to store more of cargo. This is so to avoid delay during operation and turnaround time. From the analysis of time and cost saving of Kuantan Port, it is evident that Kuantan Port is the quickest and fast route that will be beneficial to China Shipping Company in the cost of the voyage. This will attract more foreign investors to invest in Malaysia, which may indirectly increase the economic income of Malaysia. The coming of shipping liners at Kuantan Ports due to the opening of MCKIP opens the possibility of congestion at the port and indirectly requires more workers. Such as the Port of Singapore Terminals (PSA), they have good alternatives which developed Automated Guided Vehicle (AGV) prototypes that will operate $24 / 7$ for its future container port, to transport containers between the 
quay and the container yard efficiently and reliably without human drivers. It is the effective way towards effective cargo handling.

The review of this research on a measure of the attractiveness of Kuantan port and its benefits due to the opening of MCKIP would give significant impact on the economy of the country. By analysing the journey time and cost aspect of Kuantan port with the others hub port in Malaysia, it would help the China shipping liners in decision making. This study can also determine the readiness of Kuantan port to receive the main China shipping liners. In general, the ports are the leading player in the economic development of the country. The development of port entails not just by focusing on the port performance and technology use, but also the geographic location should be taken into account to meet the service efficiency.

\section{References}

Baier, S.L. and Bergstrand, J.H. (2001) The growth of world trade: tariffs, transport costs, and income similarity, Journal of International Economics, Vol. 53: 1-27.

Delahaye, B.L. (2000) Strategic human resource development. Milton: John Wiley \& Sons.

Fink, C., Mattoo, A. and Neagu, I.C. 2000 Trade in international maritime services: how much does policy matter? Mimeo World Bank: Washington, D.C.

Heinz, W. (1977) The TOWS Matrix: A Tool for Situational Analysis, Long Range Planning, February.

Hilling, D. and Hoyle, B.S. (1984) Spatial Approaches to Port Development, in Hilling, D. and Hoyle, B.S. (eds.), Seaport Systems and Spatial Change, 1-19.

Johnson, G. and K. Scholes (1989) Exploring Corporate Strategy. Hemel Hempstead, Prentice Hall.

Klink, H.A. Van (1995) Towards the Borderless Mainport Rotterdam - an analysis of functional, spatial and administrative dynamics in port systems, Amsterdam: Thesis Publishers.

Lee, R. and Sean, H.O. (2013) Malaysia-China Kuantan Industrial Park open for business, The Stars Online. 'MCKIP officially open for business from The Star online $06 \quad$ February 2013 http://www.thestar.com.my/News/Nation/2013/02/06/MCKIPofficially-open-for-business/. 
Leng, K.Y. (2013) The Significance of China-Malaysia Industrial Parks, ISEAS Perspective 2013/37, Institute of Southeast Asian Studies (ISEAS), 4654.

Magelssen, W. (2010) Energy analyses for different vessel types: what do you need to know at the design and operational stages? Paper presentation for a seminar of a practical guide to fuel management, ship performance and energy efficiency, $26^{\text {th }}-27^{\text {th }}$ January, London.

Marios, M. (2006) Improved port performance through training: The contribution of the International Labour Organization, Paper presentation for the $22^{\text {nd }}$ International Port Conference-"Human Resources and Sea Ports Performance, 12-14 March 2006, Alexandria, Egypt.

Notteboom, T.E. (1997) Concentration and the Load Center Development in the European Container Port System. Journal of Transport Geography, Vol. 5: 99-15.

Shanghai Bunker Price (2013) http://shipandbunker.com/prices/apac/ea/cn-shashanghai. [Accessed on 17 October 2013]

Stopford, M. (2003) Maritime Economics second edition. Taylor \& Francis elibrary, 151-180.

Notteboom, T.E. and Vernimmen, B. (2009) The effect of high fuel costs on liner service configuration in container shipping. Journal of Transport Geography, Vol. 17(5): 325-337.

Tongzon, J. (1995) Determinants of port performance and efficiency, Transportation Research Part A, Vol. 29(3): 245-252.

Tongzon, J. (2001) Efficiency measurement of selected Australian and other international ports using data envelopment analysis, Transport Research Part A, Vol. 35: 107-122.

Wang, S., Meng, Q. and Liu, Z. (2013) Bunker consumption optimisation methods in shipping: A critical review and extensions, Transportation Research Part E: Logistics and Transportation Review, Vol. 53: 49-62. 